\title{
NUTRISI KEDELAI PADA OBESITAS \\ DAN DISMETABOLIK SINDROM
}

\author{
Meddy Setiawan*
}

\begin{abstract}
Obesity is not only an aesthetic problems but also bas become nowadays bealth problem, it is because obesity is a risk factor to dysmetabolic syndrome sucb as diabetes, bypertension, byperlipidemia and Cononer Heart Disease. According to data from "Riset Kesebatan Dasar" (Riskestas) in 2007 Indonesia, shows that prevalence of obesity on female $>15$ years old which is $23,8 \%$ and male $>15$ years old which is 13,9\%. In other hand according "Survey Kesebatan Rumab Tangga" (SKRT) in 2001, 41\%-50\% obesity on female occurs in $>55$ years old (menopause age) (Depkes, 2007).

Obesity bappens because the energy supply is bigger than the energy used so the energy storaging bappens inside fatty cells in the form of bypertrophy and hyperplasia fatty cells. One of main regulators which is important in metabolism regulation and fat deposition inside fatty cell is estrogen (cooke, 2004). Fatty cells is proved to bave á-estrogen receptors (ERá) and â-estrogen receptors (ERâ) (Wook, 2008). Estrogen receptor effects on fatty cells is regulating fatty tissue by increasing the lipolysis and modulating the expression gene wbich is able to regulate fat deposition in fattu cells. The bigh prevalence of obesity on menopause women and the important role of estrogen in fat regulation and deposition in fatty cells, visceral or subcutan motivate the researchers to do all kind of experiments to find an exogenic estrogen sourch. Some compounds came from plants which is known as phytoestrogen, have similar activity as estrogen activity because it bas similar structure, the compounds are flavon, isoflavon, and comestans. Isoflavon could be found in peanuts, especially soybean and otber product from it (Tanu, 2005). Phytoestrogen from soybean is able to bind with estrogen receptors, even the afinity to estrogen receptors is lon compared to endogenic estrogen. So it needs phytoestrogen is buge numbers to bave same effects as endogenic estrogen (Hidayati, 2003). In condition when there is no endogenic estrogen, suc as timsin kinase patbway, mitogen activated protein kinase pathway, or epydermal growth factor patbway. Isoflavon is able to prevent fat storaging by inbibit the work of lipogenic lipoprotein lipase (r J.A.ford, 2006)

Soybeans are one of daily food ingredients in Asia. The Average consumption of soybeans in Indonesia is second greatest number in the world after japan, which is 200 grams of soybeans or product from it each day. The bigh nutrition contained in soybeans make the soybeans product could give advantages on bealth one of nutritions contained in soybeans in isoflavon. Isoflavon in soybeans, make is possible for consumption of soybeans in certain amount to bave similar effect as endogenic estrogns effect (Koswara, 2006).
\end{abstract}

Key word : Soybean nutrition - Isoflavon - Obesity - Dysmetabolic syndrome

$\rightarrow$

\section{Abstrak}

Obesitas tidak hanya menjadi masalab estetike semata tetapi juga telah menjadi masalah kesehatan utama saat ini, hal ini disebabkan karena obesitas merupakan faktor resiko terjadinya dismetabolik sindrome seperti diabetes, bipertensi, biperlipidemi dan penyakit jantung koroner. Menurut data Riset Kesebatan Dasar (Riskesdas) tabun 2007 di Indonesia, menunjukan babwa prevalensi obesitas pada wanita berusia lebih dari 15 tabun yaitu 23,8\% dan pada laki-laki berusia lebib dari 15 tabun yaitu 13,9\%. Sedanglean menurut Survei Kesebatan Rumab Tangga (SKRT) tabun 2001, 41\%-50\% obesitas pada wanita terjadi pada usia lebib dari 55 tabun (usia menopause) (Deplees, 2007).

Obesitas terjadi karena adanya asupan energi yang lebih besar daripada energi yang digunakan sebingga terjadi penimbunan energi dalam sel adiposil dalam bentuk sel adiposit yang bipertrofi dan biperplasi. Salab satu regulator utama yang penting dalam regulasi metabolisme dan deposisi lemak dalam sel adiposit adalab bormon estrogen (Cooke, 2004). Sel adiposit terbukti memiliki reseptor estrogen $\dot{a}(E R a ́)$ dan reseptor estrogen â (ERâ) (Wook, 2008). Efek reseptor estrogen pada sel adiposit adalab meregulasi jaringan adiposit dengan meningkatkan lipolisis dan memodulasi ekspresi gen yang meregulasi deposisi lemak di sel adiposity. Tingginja prevalensi obesitas pada wanita menopause dan pentingnya peranan estrogen dalam regulasi dan deposisi lemak pada sel adiposit viscera maupun subcutan, mendorong para peneliti melakukan berbagai percobaan untuk mencari sumber estrogen eksogen. Beberapa senyawa yang berasal dari tumbuhan yang dikenal

\footnotetext{
* Staff Pengajar Pada Fakultas Kedoleteran

Universitas Muhammadiyah Malang
} 
dengan fitoesirogen, mempunyai aktifitas serupa dengan aktifitas bormon estrogen karena mempunyai struktur yang mirip dengan bormon estrogen, senyawa tersebut adalab flavon, isoflavon dan derivat comestans. Isoflavon banyak terdapat pada tanaman kacang-kacangan, terutama kedelai dan produk olabannya (Tanu 2005). Fitoestrogen dari kedelai mampu berikatan dengan reseptor estrogen, walaupun afinitasnja terbadap reseptor estrogen sangat rendab dibandingkan dengan estrogen endogen sebingga diperlukan jumlab fitoestrogen yang besar untuk memperoleb efek yang memadai seperti estrogen. (Hidayati 2003). Pada keadaan tidak terdapatnya estrogen endogen, seperti pada bewan yang dionariektomi, isoflavon dapat bekerja melalui jalur alternatif, seperti jalur tirosin kinase, jalur mitogen-activated protein kinase, atan jalur epidermal growth factor. Isoflavon dapat mencegah penimbunan lemak dengan meghambat kerja enzim lipogenik lipoprotein lipase (fr J.A. ford, 2006).

Kedelai adalab salab satu bahan makanan sehari-bari penduduk di Asia. Rata-rata konsumsi kedelai masyarakat Indonesia menempati urutan kedua di dunia setelab Jepang, yaitu 200 gram produk kedelai atau olabannya per bari. Tingginya kandungan gizzi dalam kedelai menjadikan produk kedelai dapat memberikan manfaat bagi kesebatan. Salab satu kandungan gizi dalam kedelai adalab isoflavon. Adanya kandungan isoflavon pada kedelai, memungkinkan konsumsi kedelai dalam jumlah tertentu dapat memberikan efek serupa dengan efek bormon estrogen endogen. (Koswara, 2006).

Key word : kedelai - isoflavon - obesitas - dismetabolik sindrome

\section{Histofisiologis Jaringan Adiposit}

Jaringan adiposit (lemak) adalah jenis jaringan ikat khusus, yang terutama terdiri dari adiposit. Sel-sel ini tersebar sendiri-sendiri atau berupa kelompok kecil dalam jaringan ikat; kebanyakan sel lemak terdapat dalam kelompok besar, yang membentuk jaringan adiposit yang tersebar di seluruh tubuh. Jaringan adiposit, secara kasar, dapat dianggap sebagai salah satu organ terbesar di tubuh. Pada pria dengan berat badan normal, jaringan adiposit merupakan $15-20 \%$ dari berat badannya; sedangkan pada wanita dengan berat badan normal, mencapai $20-25 \%$ dari berat badannya (Junquira, 2007).

Jaringan adjposit merupakan gudang energi terbesar (dalam bentuk trigliserida) di tubuh. Organ lain yang menimbun encrgi (dalam bentuk glikogen) adalah hati dan otot rangka. Karena makan merupakan aktivitas yang rutin dan pasokan glikogen memiliki keterbatasan, sejumlah kalori dapat terpakai di antara waktu-waktu makan. Karena densitas trigliserida lebih rendah dibandingkan glikogen dan memiliki nilai kalori yang lebih tinggi $(9,3 \mathrm{kkal} / \mathrm{g}$ untuk trigliserida, $4,1 \mathrm{kkal} / \mathrm{g}$ untuk karbohidrat), jaringan adiposit merupakan jaringan penimbunan yang sangat efisien. Jaringan ini terus menerus mengalami penggantian dan sensitif terhadap rangsang syaraf dan hormonal. Jaringan adiposit subkutan membantu membentuk permukaan tubuh, sedangkan yang terdapat dalam bentuk bantalan berfungsi sebagai peredam goncangan, terutama di telapak tangan dan telapak kaki. Akhir-akhir ini diketahui bahwa jaringan adiposit menyekresi berbagai jenis molekul yang dibawa oleh darah untuk memengaruhi organ yang letaknya jauh. Berdasarkan lokasi, struktur, warna dan ciri patologis dikenal 2 jenis lemak, yaitu lemak putih (jaringan lemak unilokuler) dan lemak cokelat (jaringan lemak multilokuler) (Junquira, 2007).

\section{Penimbunan dan Mobilisasi Lipid Pada Adiposit}

Obesitas adalah keadaan diamana indeks masa tubuh (IMT) sescorang yang didapat dari pembagian berat badan (kilogram) terhadap kuadrat tinggi badan (meter) melcbihi 25. Di negara maju, obesitas (kegemukan) merupakan masalah kcschatan utama. Kelebihan jaringan lemak menambah beban sistem sirkulasi, meningkatkan resiko hipertensi dan infark miokard. Obesitas yang berkembang selama masa kehidupan dewasa, biasanya disebabkan olch pengumpulan lipid berlebihan dalam sel lemak unilokular yang berjumlah normal (obesitas hipertrofik). Sel lemak pada orang demikian dapat mencapai ukuran empat kali besar biasanya. Pada obesitas berat jumlah selnya mungkin melebihi normal (obcsitas hipersel). Sel lemak berdefrensiasi sempurna tidak dapat membelah lagi dan prekusornya yang terbentuk selama masa awal pascanatal tidak dapat berproliferasi di kemudian hari, namun jumlah prekusor sel adipositnya bervariasi. Kini ada bukti eksperimental maupun klinik bahwa kebanyakan makan semasa minggu-minggu pertama kehidupan dapat berakibat terbentuknya jumla prekusor adiposit yang melebihi normal, yang berakibat meningkatnya bahaya terjadinya obesitas hipersel di saat dewasa. Data klinik menunjukkan bahwa bayi dengan berat badan di atas persentil ke-97, tiga kali lebih besar kemungkinannya untuk menjadi gemuk saat dewasa. Jadi jelaslah bahwa tingkat nutrisi semasa awal kehidupan dapat mempengaruhi jumlah prekusor sel lemak. Jika obesitas hipertrofik dapat terjadi kepada sembarang orang akibat kelebihan makan, obesitas hipersel lebih besar kcmungkinan terjadi pada mereka yang semasa bayinya kegemukan (Junquira, 2007).

Jaringan adiposit adalah depot energi yang besar bagi organisme. Lipid dalam adiposit terutama berupa trigliserida, yaitu ester dari asam lemak dan gliserol. Asam 
lemak yang ditimbun sel-sel ini berasal dari lemak makanan yang dibawa ke sel adiposit dalam bentuk kilomikron trigliserida, yang disintesis di hati dan dibawa ke sel-sel dalam bentuk VLDL (very low density lipid) (Junquira, 2007).

Kilomikron adalah partikel berdiameter sampai $3 \mu \mathrm{m}$, yang dibentuk di sel epitel usus dan dibawa dalam plasma darah dan cairan limfe mesenterium. Partikel ini terdiri atas bagian pusat, terutama terdiri atas trigliserida dan sedikit ester kolesterol, yang dikelilingi lapisan penstabil yang terdiri atas apolipoprotein, kolesterol dan fosfolipid. VLDL memiliki lebih banyak lipid di lapisan permukaannya karena partikel ini lebih kecil (menghasilkan rasio permukaan-volume yang lebih besar), memiliki berbagai apolipoprotein di permukaan dan memiliki proporsi ester kolesterol terhadap trigliserida yang lebih besar dibandingkan dengan kilomikron. Kilomikron dan VLDL dihidrolisis di permukaan lumen kapiler darah di jaringan adiposit oleh lipase protein, yakni suatu enzim yang disintesis oleh adiposit dan diangkut ke membran sel kapiler. Asam lemak bebas memasuki adiposit melalui mekanisme yang belum dipahami. Agaknya sistem transport aktif dan difusi bebas ikut terlibat dalam proses tersebut. Vesikel pinositotik yang banyak dijumpai di permukaan adiposit agaknya tidak terlibat. Asam lemak menembus lapisan lapisan berikut (berturut-turut) dari endotel kedalam sel adiposity : endotel kapiler, lamina basal kapiler, substansi dasar jaringan ikat, lamina basal adiposit, membran plasma adiposit. Pergerakan asam lemak melalui sitoplasma ke dalam tetes lipid belum dimengerti sepenuhnya, sangat mungkin melibatkan protein pembawa yang spesifik. Di dalam adiposit, asam lemak bergabung dengan gliserol fosfat, suatu produk antara dari metabolisme glukosa, untuk membentuk molekul trigliscrida. Molekul ini kemudian ditimbun di dalam tetes trigliserida. Mitokondria dan retikulum endoplasma halus merupakan organela yang berpartisipasi aktif pada proses ambilan dan penyimpanan lipid (Junquira, 2007).

Sel adiposit dapat menyintesis asam lemak dari glukosa, yakni suatu proses yang dipercepat oleh insulin. Insulin juga merangsang ambilan glukosa ke dalam sel adiposit dan meningkatkan sintesis lipase lipoprotein (Junquira, 2007).

Lipid yang ditimbun dapat dimobilisasi melalui mekanisme humoral dan neurogenik yang berakibat pelepasan asam lemak dan gliserol kedalam darah. Lipase trigliserida suatu enzim yang dikenal dengan 'lipase peka hormon', diaktifkan oleh adenilat siklase jika jaringan dirangsang oleh norepinefrin. Norepinefrin dibebaskan pada ujung syaraf simpatis pascaganglionik, yang terdapat di jaringan adiposit. Enzim yang teraktifkan merombak molekul trigliserida, yang terutama berada pada permukaan tetes lipid. Asam lemak yang relatif tidak larut dipindahkan bersama albumin ke jaringan tubuh lainnya, sedangkan gliserol yang lebih mudah larut tetap bebas dan diambil oleh hati (Junquira, 2007).

Hormon pertumbuhan, glukokortikoid, prolaktin, kortikotropin insulin dan hormon tiroid juga berperan pada berbagai tahap metabolisme jaringan adiposit (Junquira, 2007).

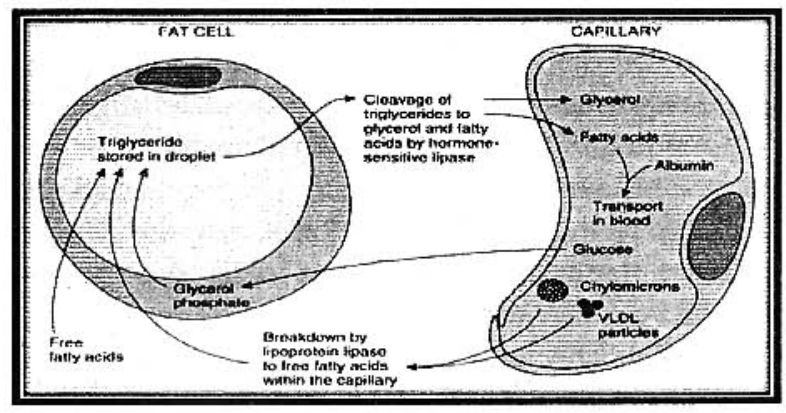

(Wolfrum, 2008)

Gambar 1. Mobilisasi lipid pada sel adiposit unilokular

Jaringan adiposit juga berfungsi sebagai organ sekresi. Jaringan ini menyintesis beberapa molekul yang terbawa oleh darah atau tetap melekat pada endotel kapiler di sekitar adiposit (misalnya lipoprotein lipase). Zat yang diproduksi sel adiposit dan paling banyak dipelajari adalah leptin, yakni suatu protein yang terdiri atas 164 asam amino. Beberapa sel di otak dan juga jaringan lain memiliki reseptor untuk leptin. Molekul ini berpartisipasi dalam pengaturan jumlah jaringan adiposa dalam tubuh dan asupan makanan. Zat ini terutama bekerja di hipotalamus untuk mengurangi asupan makanan dan meningkatkan penggunaan energi (Junquira, 2007).

Cabang simpatis dari susunan saraf otonom menyarafi jaringan adiposit unilokular maupun multilokular. Pada jaringan adiposit unilokular, ujung saraf hanya ditemukan pada dinding pembuluh darah; adiposit tidak disarafi secara langsung. Pelepasan neurotransmitter norepinefrin akan mengaktifkan lipase peka hormon. Persarafan ini berperan penting pada mobilisasi lemak (Junquira, 2007).

Sebagai respon terhadap kebutuhan badan, lipid tidak dimobilisasi secara seragam di seluruh tubuh. Lapisan subkutan, mesentrik dan retroperitoneal adalah lapisan yang pertama kali dimobilisasi, sedangkan jaringan adiposit yang berada di tangan, kaki, dan bantalan lemak retroorbita tahan lama terhadap starvasi yang betkepanjangan. Setelah masa starvasi tersebut dilalui, jaringan lemak unilokuler kehilangan hampir seluruh lemaknya dan mengandung sel-sel polyhedral atau berbentuk kumparan dengan sejumlah kecil tetes lipid (Junquira, 2007). 


\section{Efek Hormon Estrogen Pada Sel Adiposit}

Faktor-faktor yang meregulasi sel adiposit unilokular saat ini menjadi pethatian para peneliti, hal ini karena meningkatnya kasus obesitas dan komplikasi yang ditimbulkannya. Hormon adalah salah satu faktor utama yang penting bagi perkembangan dan fungsi dari jaringan adiposit. Paparan terhadap berbagai macam hormon dapat mempengaruhi metabolisme dan perkembangan sel adiposit, termasuk hormon pertumbuhan, hormon tiroid, hormon insulin, glucagon dan estrogen. Jaringan adiposit adalah jaringan yang sangat responsif terhadap rangsang estrogen. Jaringan adiposit pada tikus dan manusia memiliki estetogen rescptor tipe alfa (ERá) maupun tipe beta (ERâ). Hilangnya estrogen dalam sirkulasi karena proses ovariektomi mongakibatkan meningkatnya berat badan dan berat sel adiposit, dan hal ini dapat diperbaiki atau dicegah oleh terapi sulih hormon estrogen. (Naaz, 2003).

Estrogen telah lama diketahui menjadi faktor utama dalam regulasi metabolisme adiposit dan deposisi lemak dalam sel adiposit. Beberapa tahun ini telah diketahui efek estrogen terhadap adiposit lebih luas dan lebih kompleks daripada yang diperkirakan sebelumnya. Saat ini estrogen telah terbukti memainkan pcran penting dalam regulasi dan deposisi baik di wanita maupun pria dan telah terbukti memberikan pengaruh terhadap jumlah sel adiposit, yang mengindikasikan bahwa estrogen juga memainkan peranan penting pada proses adipogenesis. Reseptor estrogen klasik (ERá), sepertinya menjadi regulator yang penting dalam pada jaringan adiposit, tapi penelitian terbaru juga menunjukan adanya efek dari reseptor estrogen â (Cook, 2004).

Estrogen bisa mempengaruhi sel adiposit secara tidak langsung dengan memodulasi selera makan atau penggunaan energi. Estrogen juga secara langsung menurunkan aktifitas lipo protein lipase (LPL), sebuah enzim lipogenik yang meregulasi ambilan lipid. Ovariektomi meningkatkan aktifitas LPL dan deposisi lemak di sel adiposit dan pemberian 17â Estradiol terbukti dapat mencegah proses ini (Naaz, 2003).

Beberapa penelitian fokus terhadap kemampuan estrogen dalam mempengaruhi fungsi dan morfologi dari sel adiposit, menyatakan bahwa sel adiposit adalah salah satu jaringan yang menjadi target utama hormon estrogen. Estrogen sccara tidak langsung juga dapat meregulasi sel adiposit melalui jaringan lain yang meregulasi nafsu makan, pemakaian energi dan metabolisme. Reseptor estrogen tersebar luas di hypothalamus, daerah utama di otak yang mengatur keseimbangan energi, dan saat ini efek estrogen terhadap ambilan dan penggunaan energi tclah diketahui. Disebutkan juga reseptor estrogen juga ditemukan di organ lain seperti liver, dimanan efek estrogen dapat menghasilkan perubahan metabolisme yang juga akan mempengaruhi deposisi sel adiposit di seluruh jaringan adipose (Cook, 2004).

\section{Efek Estrogen Secara Langsung Pada Sel Adiposit}

Estrogen dapat secara langsung menghambat deposisi sel adiposit dengan menurunkan proses adipogenesis. Hal ini terjadi katena menurunnya aktifitas lipoprotein lipase (LPL), sebuah enzim yang meregulasi ambilan lipid oleh sel adiposit. Ovariektomi terbukti meningkatkan LPL dan deposisi lemak di sel adiposit dan pemberian dosis fisisologis estrogen terbukti dapat mengembalikan dan menghentikan proses ini. Penelitian terakhir pada 3T3 di sel adiposit menyebutkan bahwa LPL mempunyai cfek negatif terhadap elcmen respon estrogen (Cook, 2004).

Esrogen dapat juga meningkatkan lipolisis secara tidak langsung, dengan menginduksi enzim lipolisis hormon-sensitif lipase atau dengan meningkatkan aktifitas lipolisis dari epinefrin, meningkatkan oksidasi asam lemak, yang akhirnya juga dapat mengakibatkan menurunnya deposisi lipid pada sel adiposit. Berkebalikan dengan efek antilipogenesis dan lipolisis tersebut, estrogen justru meningkatkan efek á2A-adrenergik reseptor di jaringan lemak subkutan di manusia dan menurunkan lipolisis, efek ini dapat berperan pada peningkatan deposisi lemak subkutan pada wanita dibandingkan pada pria (Cook, 2004).

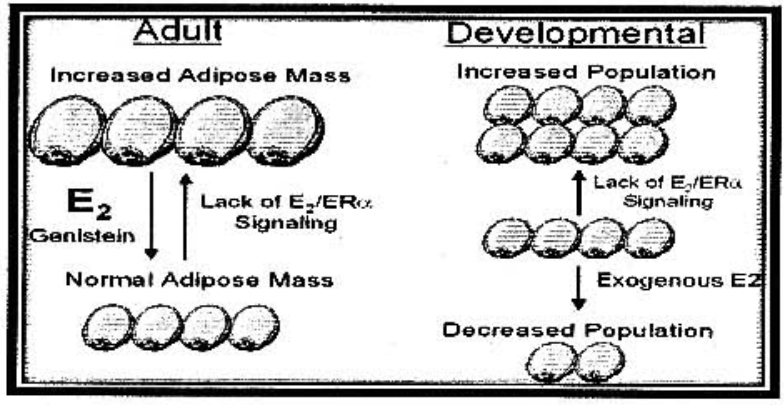

(Cook, 2004)

Gambar 2. Efek estrogen terhadap adipogenesis dan lipogenesis Tidak adanya rangsang estrogen seperti pada menopause dapat meningkatkan deposisi lemak dalam bentuk hipertrofi dan hiperplasi sel adiposit 


\section{Efek Estrogen Pada Ambilan Energi dan Penggunaan Energi}

Estrogen memiliki efek negative terhadap peningkatan nafsu makan di hipotalamus. Ketika tikus yang di-ovariektomi dibandingakan dengan tikus yang tidak di-ovariektomi dibandingakan, tikus yang diovariektomi mengalami peningkatan berat badan yang lebih tinggi, baik pada tikus yang hiperfagia maupun yang tidak. Hal ini mengindikasikan bahwa estrogen memiliki efek dalam konsumsi makanan, efek sentral dari estrogen ini berhubungan dengan penurunan deposisi lemak di sel adiposit namun mungkin bukan keseluruhan efek dari penurunan ambilan energi. Aspek yang lain dari efek sentral estrogen bisa mempengaruhi penggunaan energi. Tikus yang di-áERKO menunjukan penurunan pemakaian encrgi, hal ini mengindikasikan aksi dari estrogen pada penggunaan energi melalui jalur reseptor á (Cook, 2004).

Penelitian yang dilakukan akhir-akhir ini menyebutkan bahawa produksi leptin juga dipengaruhi oleh estrogen. Bahkan disimpulkan bahwa estrogen tidak hanya dapat mempengaruhi produksi leptin melalui reseptor alfa estrogen namun juga reseptor beta estrogen. Ditambahkan bahwa efek yang dihasilkan dari jalur reseptor alfa berkebalikan dengan jalur pada reseptor beta. Dengan kata lain estrogen memberikan efek pada produksi leptin bukan berdasarkan level estrogen melainkan melalui ekspresi reseptor alfa atau beta (Wook, 2008).

Leptin dihasilkan di adiposit dan berikatan dengan reseptornya di hipotalamus untuk kemudian mempengaruhi pengambilan dan pemakaian energi. Kondisi hipoestrogen lebih dari 5 bulan dapat meningkatkan deposisi lipid dan meningkatkan jaringan adiposit sehingga kadar leptin dalam sirkulasi meningkat, hal ini akan meningkatkan penyimpanan energi (Cook, 2004).

Tabel 1. Efek estrogen pada jaringan adiposit

\begin{tabular}{|c|c|}
\hline \begin{tabular}{|l} 
Efck \\
Langsung
\end{tabular} & 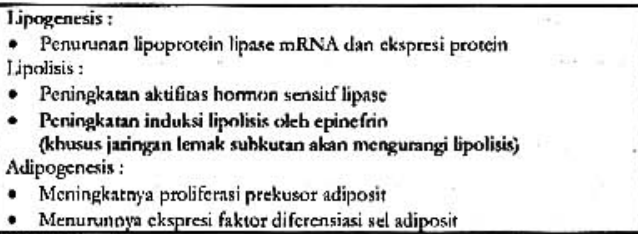 \\
\hline $\begin{array}{l}\text { Efek } \\
\text { sentral }\end{array}$ & 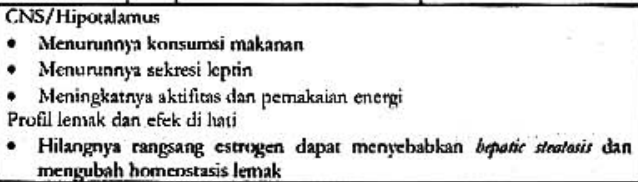 \\
\hline
\end{tabular}

(Cook, 2004)
Efek Isoflavon Kedelai Pada Sel Adiposit

Kedelai (Glycine max (L)) Merill), diduga berasal dari kedelai liar Cina, Manchuria, dan Korea. Rhumpius melaporkan bahwa pada tahun 1750 kedelai sudah mulai dikenal sebagai bahan makanan dan pupuk hijau di Indonesia. Kedelai merupakan salah satu tanaman sumber protein yang penting di Indonesia. Berdasarkan luas panen, di Indonesia kedelai menempati urutan ketiga sebagai tanaman palawija setelah jagung dan ubi kayu. Rata-rata luas pertanaman pertahun sekitar 703.878 ha, dengan total produksi 518.204 ton. (Riwi, 2006)

Protein dalam kedelai dapat membantu menurunkan resiko penyakit kardiovaskular dengan menurunkan kadar kolesterol dan meningkatkan fleksibilitas dari pembuluh darah. Kedelai juga mengandung nutrisi-nutrisi penting yang telah menunjukan bukti yang nyata dalam menununkan keluhan gejala-gejala menopause, menjaga kesehatan tulang, dan mencegah kankern (Riwi, 2006)

Tabel 2. Kandungan Nutrisi dalam Kedelai

\begin{tabular}{|l|l|l|l|l|l|l|l|l|l|l|l|}
\hline Bahan & & & & & & & & & & & \\
\hline $\begin{array}{l}\text { Biji } \\
\text { kedelai } \\
\text { kering }\end{array}$ & 8 & 331 & 34,9 & 18,1 & 34,8 & 227 & 585 & 8,0 & 110 & 1,07 & 0 \\
\hline $\begin{array}{l}\text { Tepun } \\
\text { g } \\
\text { kedelai }\end{array}$ & 9 & 547 & 35,9 & 20,6 & 29,9 & 1295 & 614 & 9,5 & 0 & 0,93 & 5,8 \\
\hline
\end{tabular}

Hasil-hasil penelitian di berbagai bidang kesehatan telah membuktikan bahwa konsumsi produkproduk kedelai berperan penting dalam menurunkan resiko terkena berbagai penyakit degeneratif. Ternyata, hal tersebut salah satunya discbabkan adanya zat isoflavon dalam kedelai. Isoflavon merupakan faktor kunci dalam kedelai sehingga memiliki potensi memerangi penyakit tertentu (Koswara, 2006).

Isoflavon adalah tipe flavonoid yang ditemukan di tumbuhan. Isoflavon dalam kedelai yang biasa disebut juga dengan fitoestrogen, saat ini sedang mendapat perhatian yang besar dari para peneliti, hal ini karena kemampuannya dalam melawan penyakit kronik seperti kanker dan penyakit kardiovaskular. Dari beberapa macam isoflavon yang ditemukan dalam kedelai, genistcin menunjukan aktifitas yang sangat besar pada beberapa penelitian di manusia dan hewan. Genistein pada umumnya ditemukan dalam bentuk glikosida genistein dan glikosida 6"-O-malonilgenistein dan 6"-Oasetilgenistein. Sebutan "genistein" biasanya diberikan untuk "genistein a-glikon". Genistein dan glikosidanya banyak ditemukan di tanaman polong-polongan, seperti kedelai dan 'chickpea' (Gaur, 2008). 
Fitoestrogen yang secara alami dapat di temukan di tumbuh-tumbuhan, merupakan senyawa yang struktur dan fungsinya mirip dengan estradiol. Saat ini terdapat 4 kelas utama fitoestrogen : isoflavon, senyawa ini biasa ditemukan dalam kedelai dan produk turunannya; flavonoid, biasa ditemukan di buah-buahan; lignans, biasanya terdapat dalam tepung, sereal, dan kacangkacangan; comestans, ditemukan di kacang-kacangan dan alfafa. Isoflavon adalah senyawa fitoestrogen yang memiliki aktifitas cstrogenik yang paling poten, diantaranya adalah genistein daidzein dan glycitein yang dapat ditemukan dalam kedelai, senyawa isoflavon tersebut adalah yang paling aktif (Aguiar, 2006).

Isoflavon dapat berikatan lemah dengan reseptor esterogen (affinitas ikatan isoflavon $100 \mathrm{kali}$ lebih lemah dari estradiol). Kemampuan berikatan dengan reseptor estrogen ini disebabkan oleh adanya gugus hidroksil dan jarak antar gugus hidroksil yang sama dengan gugus yang ditemukan pada 17-â estradiol. Oleh karena itu, isoflavon yang berikatan dengan reseptor estrogen akan membentuk kompleks fungsional seperti yang dibentuk oleh ikatan estradiol dengan reseptornya. Isoflavon dalam kedelai (genistein, daidzein) berikatan dengan baik dengan reseptor â-estrogen yang dapat ditemukan di sistem saraf pusat, tulang, dinding pembuluh darah dan traktus urogenitalia. Tidak seperti estrogen, ikatan antara isoflavon dengan reseptor á-estrogen yang ditemukan di payudara dan dinding uterus, ikatan reseptornya lemah (Aguiar, 2006).

Pemberian nutrisi kedelai peroral akan mengaktifkan kompleks enzim metabolik dalam traktus gastrointestinal, yang akan menghasilkan heterosiklik fenol yang strukturnya mirip dengan 17-â estradiol. Setelah diserap oleh sel enterosit, senyawa isoflavon akan mencapai sirkulasi dan akan disekresikan setelah 7-8 jam kemudian. Isoflavon aglikon (genistein, daidzein, glycitein) adalah bentuk yang aktif yang telah diabsorbsi. Rasio absorbsi berkisar antara 20\%-55\%. Konsentrasi dari berbagai macam isoflavon yang ada dalam makanan dan efek yang dapat ditimbulkan sangat bervariasi. Oleh karena itu, sangat sulit untuk menentukan dosis optimal, beberapa peneliti menganjurkan dosis ideal $30 \mathrm{mg}$ sampai $100 \mathrm{mg}$ per hari (Aguiar, 2006).

Beberapa penelitian telah dilakuakan mengenai efek Isoflavon dalam tubuh. Berikut ini adalah beberapa efek Isoflavon yang telah diketahui : aktivitas inhibisi tirosin kinase, aktivitas anti oksidan, aktivitas estrogenik dan anti estrogenik, regulasi enzim $\mathrm{p} 53$, aktivitas anti kanker, aktivitas penurunan kadar lemak, aktivitas anti obesitas dan imunomodulator (Gaur, 2008).
Tabel 3. Kandungan isoflavon dalam makanan

\begin{tabular}{|l|c|c|c|c|}
\hline Makanan & $\begin{array}{c}\text { Total } \\
(\mu \mathrm{g} / \mathrm{g})\end{array}$ & $\begin{array}{c}\text { Genestein } \\
(\mu \mathrm{g} / \mathrm{g})\end{array}$ & $\begin{array}{c}\text { Daidzein } \\
(\mu \mathrm{g} / \mathrm{g})\end{array}$ & $\begin{array}{c}\text { Glicytein } \\
(\mu \mathrm{g} / \mathrm{g})\end{array}$ \\
\hline $\begin{array}{l}\text { Roasted } \\
\text { soybeans }\end{array}$ & 2661 & 1426 & 941 & 294 \\
\hline $\begin{array}{l}\text { Textured } \\
\text { soy protein }\end{array}$ & 987 & 640 & 191 & 156 \\
\hline Tempe & 865 & 422 & 405 & 38 \\
\hline Tofu & 532 & 245 & 238 & 49 \\
\hline Soy drink & 28 & 21 & 7 & - \\
\hline
\end{tabular}

(Aguiar, 2006)

Konsumsi isoflavon telah menunjukan efek yang berarti pada sel adiposit, seperti menginduksi apoptosis, mencegah akumulasi lemak dan merangsang terjadinya lipolisis. Selain efek estrogenik terhadap sel adiposit, fitoestrogen seperti genistein juga mampu mencegah terjadinya obesitas dengan bekerja pada siklus perkembangan sel adiposit. Sehingga strategi ini dapat digunakan sebagai metode untuk pencegahan dan terapi pada obesitas akibat kondisi hipoestrogen seperti pada menopause (Rayalam, 2007).

\section{Efek Isoflavon Pada Sel Adiposit Perkembangan preadiposit}

Preadiposit dapat berproliferasi untuk meningkatkan jaringan adiposit. Beberapa produk dari tumbuhan telah menunjukan aktifitas dalam menghambat proliferasi dari preadiposit. Isoflavon dapat menginduksi apoptosis pada sel preadiposit, hal ini berkaitan dengan aktifitas antioksidan yang dimiliki. Genistein salah satu isoflavon yang banyak terdapat dalam kacang-kacangan, mampu menginduksi terjadinya apoptosis sel preadiposit dengan menurunkan potensial membran pada mitokondria. Diduga genistein juga mampu menghambat mitosis preadiposit pada fase $G_{1}$ namun mekanismenya belum banyak diketahui (Rayalam, 2007).

\section{Pematangan preadiposit}

Peningkatan jumlah sel adiposit tidak hanya disebabkan terjadinya proliferasi preadiposit, akan tetapi juga karena terjadinya diferensiasi. Induksi untuk terjadinya difernsiasi akan menstimulasi terjadinya aktifitas mitosis yang disebut clonal expansion. Genistein telah diketahui menghambat terjadinya mitosis clonal expansion pada 3T3L1 preadiposit. (Rayalam, 2007).

\section{Adipogenesis}

Awal terjadinya adipogenesis pada sel preadiposit adalah ketika terjadi perubahan level dari ekstraseluler matriks dan perubahan komponen sitoskeleton. Perubahan tersebut diketahui karena adanya aktifitas faktor transkripsi adipogenik antara lain C/EBPá dan PPARã. C/EBPá dan PPARã adalah regulator transkripsional adipogenesis dan dibutuhkan dalam pembentukan beberapa protein 
fungsional di sel adiposit. Beberapa penelitian menunjukan bahwa senyawa seperti genistein, EGCG, barbarin dan lain-lain, mampu menghambat proses adipogenesis. Penelitian menyebutkan bahwa pemberian genistein, barbarin dan capsaicin menurunkan jumlah dari C/EBPá dan PPARã (Rayalam, 2007)

\section{Lipolisis}

Pemecahan trigliserida (TG) menjadi asam lemak dan gliserol adalah hal yang penting dalam mengatur keseimbangan akan kebutuhan energi. Hormon sensitif lipase (HSL) adalah enzim yang mengkatalisa terjadinya lipolisis. HSL adalah salah satu sasaran dari regulasi adiposit olch beberapa hormon metabolik scperti insulin. Penelitian terdahulu menyebutkan bahwa, injeksi genistein, diadzein dan coumestrol dapat menstimulasi terjadinya lipolissi pada tikus. Senyawa tersebut mampu mengaktifkan lipase sensitif hormon (HSL) yang merupakan katalisator lipolisis (Rayalam, 2007)

\section{Apoptosis sel adiposit}

Reactive oxygen species (ROS) telah diketahui memiliki peranan penting dalam signaling antar sel. Genistein, EGCG, dan capsaicin diketahui mampu merangsang pengeluaran ROS intraseluler yang akan mengaktifasi AMPK (AMP-activated protein kinase) sehingga terjadi apoptoasis. (Rayalam, 2007)

\section{Efek Isoflavon Kedelai Terhadap Keseimbangan Energi}

Genistein merupakan isoflavon yang paling banyak ditemukan dalam kedelai, mempunyai struktur heterosiklik difenolik yang mirip dengan estrogen. Telah terbukti bahwa genistein dapat menurunkan nafsu makan, menurunkan berat badan, dan timbunan lemak pada tikus yang di ovariektomi. Genistein terbukti mampu menghambat penimbunan lemak pada sel adiposit dan juga menghambat proliferasi sel adiposit dan meningkatkan lipolisis (Park, 2008)

Reseptor estrogen tersebar luas di hypothalamus, daerah utama di otak yang mengatur kescimbangan energi. Saat ini efek estrogen terhadap ambilan dan penggunaan energi telah diketahui. Disebutkan juga reseptor estrogen juga ditemukan di organ lain seperti liver, dimana cfek estrogen dapat menghasilkan perubahan metabolisme yang juga akan mempengaruhi deposisi sel adiposit di seluruh jaringan adipose. Adanya kemiripan struktur isoflavon dengan estrogen, memungkinkan isoflavon dapat berikatan dengan reseptor estrogen dan memberikan efek yang serupa dengan isoflavon (Cook, 2004).

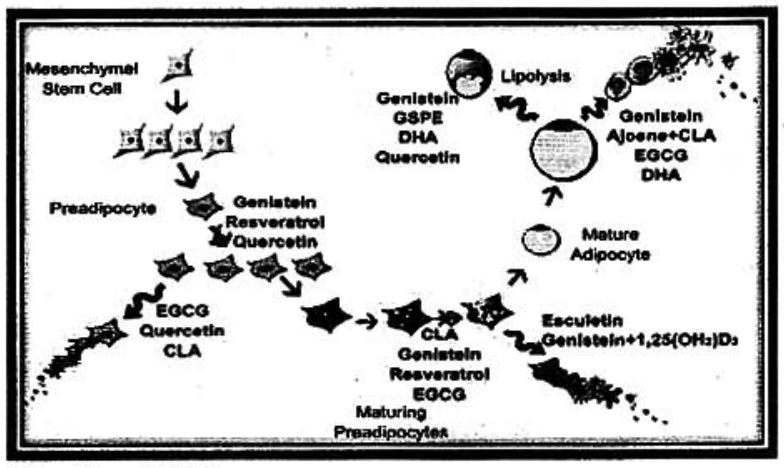

(Rayalam, 2007)

Gambar 3. Kerja beberapa fitoestrogen dalam perkembangan sel adiposit. Genistein menghambat proliferasi preadiposit dan menekan penimbunan lemak dalam proses pematangan preadiposit. Genistein juga merangsang apoptosis di sel adiposit matur dan dapat mengindiksi apoptosis sel adiposit

\section{DAFTAR PUSTAKA}

Aguiar Eliana, Petri Nahas, Jorge Nahas Neto, 2006, The Effect of Soy Isoflavones in Postmenopausal Woman, Curent drug therapy, vol 1: 31-36

Cooke Paul S, Afia Naaz, 2004, Role of Estrogen in Adipocyte Development and Function, society of experimental biology and medicine, vol 1, 15353702/04/22911-1127

Departemen Kesehatan Republik Indonesia, 2009, Obesitas dan Kurang Aktivitas Fisik Menyimbang 30\% Kanker, downloaded 26 July 2010,http:// w w w. d e p k e s.g o. i d / index.php?option $=$ news\&task $=$ viewarticle $\&$ sid $=3328$

Gaur Ajay, Arvind Lal Bhatia, 2008, Genistein: A Multipurpose Isoflavon, International Journal of Green Pharmacy, vol.1:176-183 downloaded 5 may 2010, http://www.greenpharmacy.info/temp/ IntJGreenPharm33176-3516008_094600.pdf

Hidajat A., Ali M, Kumalaningsih S, Priyoutomo E, 2003, Identifikasi dan Isolasi Isoflavon Non Kedelai Tumbuhan Polong, Simposium Nasional Persatuan Menopause Indonesia dan Asia Pasifik, Menopause Federation, Jakarta.

Hidayati, 2003, Peran Isoflavon Untuk Kesebatan Reproduksi Wanita, Cermin Dunia Kedokteran 193.

Jr J.A. Ford., S.G. Clark, 2006, Estrogenic Effect of Genistein on reproductive tissue of Ovariectomized Gilts, Journal of Animal Science, vol 1:123-234

Junqueira Luiz Carlos, Carneiro Jok, 2007, Histologi Dasar Teks \& Atlas Edisi 10, EGC, Jakarta. 
Koswara Sutrisno, 2006, Isoflavon, Senyawa Multi-Manfaat dalam Kedelai, E-bookPangan, Institut Pertanian Bogor.

Naaz Afia, Srikanth Yellayi, 2003, The Soy Isoflavone Genistein Decrease Adipose Deposition in Mice, Endocrinology, 144(8):3315-3320.

Rayalam Srujana, Mary Anne Della-Fera, 2007, Phytochemicals and regulation of the adipocyte life cycle, Journal of Nutritional Biochemistry, vol 19: 717-726.

Riwi Tri Harjanti, 2006, Pengaruh Pemberian Tepung Kedelai Terhadap Kadar Asam Urat dalam Tikus Putih, Sarjana Sains Universitas Negeri Semarang, Semarang

Tanu 1, 2005, Farmaklogi dan Terapi, Ed 4, Jakarta: Bagian Farmakologi Fakultas Kedokteran Universitas Indonesia

Wolfrum Christian et al, 2008, Mature Adipocyte Function, institute of molecular systems biology, vol 1:1-3.

Wook Kyong, Jung ho Shin, 2008, Role of Estrogen Receptor $\dot{a}$ and $\hat{a}$ in Regulating Leptin Expression in 3T3-L1 Adipogttes, Obesity, vol 16, number 11: 2393-2400. 